\title{
Can Proximity with Resource-Endowed Economies Influence FDI Inflow? the Case of Rwanda
}

\author{
Antoine Matemane Mahirwe, Wei Long
}

\begin{abstract}
The purpose of this study was to investigate if a country with limited natural resources can benefit from its geographic location due to the presence of countries in its neighborhood which are rich in natural resources. This study asserted that to benefit from other countries factors endowments, a country has to focus on enhancing other factors which are poorly achieved in neighboring countries. This study found that by focusing on improving investment and regulatory environment, Rwanda has tremendously benefited from its proximity with countries rich in natural resources but with low performance in terms of regulations and investment climate. The Johansen test reveals that in the long run, proximity exerts a positive influence on FDI inflow. However, as revealed by VECM test, in the short run the country may not benefit as it requires time to develop its investment and regulatory institutions.
\end{abstract}

\section{Index Terms - Natural resources, FDI, Proximity.}

\section{INTRODUCTION}

The economy of Rwanda is characterized by agricultural production mainly for subsistence purpose, limited natural resources, insignificant industrial sector, and low level of human capital development. In addition to that, Rwanda is a landlocked country with limited natural resources. Rwanda population density was reported at 467 people $/ \mathrm{km}^{2}$ in 2017 [1], among the highest in Sub-Saharan Africa; this is putting enormous pressure on available arable land. This puts Rwanda at a disadvantage as far as attracting foreign investors is concerned.

However, the country has managed to turn some of its disadvantages into advantages, namely its geographic location. To achieve that, Rwanda made tremendous efforts to improve both its regulatory and investment environment. Since 1994, Rwanda has maintained a social and political stability and has been well ranked for its strong and effective institutions. In 2018 Rwanda was ranked $41^{\text {st }}$ from $158^{\text {th }}$ in 2006 on ease of doing business index, whereas other regional and neighboring countries made slight and sluggish improvement, or remained virtually stagnant (See Table 1 ). Its position abruptly changed from 143 in 2009 to 67 in 2010, becoming the best performer in this area; since then, Rwanda has managed to maintained its position as the best performer vis-à-vis other regional and neighboring countries. In 2018, its Distance to Frontier was 74.4 followed by Kenya with 65.15 [3] . Therefore, it can be rightly argued that Rwanda enjoys a competitive advantage

Antoine Matemane Mahirwe, Wuhan University of Technology, China. (Email: hirwa77@ hotmail.com)

Wei Long, Wuhan University of Technology, China. (Email: 907947535@qq.com)
Revised Manuscript Received on December 30, 2019.

over other regional and neighboring economies as far as favorable business environment is concerned.

Rwanda has done a commendable job in the area of the fight against corruption and promotion of transparency, in fact, its performance in this regard has scored higher than other neighboring and regional countries; as shown in Fig. 1, the corruption perception index (CPI score) has been above that of other neighboring and regional countries, in 2017 it was 55 followed by Tanzania with only 36. According to World Economic Forum [4], Rwanda ranks $58^{\text {th }}$ and remains among the most competitive African countries thanks to its efficient goods and labor markets and a stable political situation that supports robust GDP growth. This reports points to lower health and primary education, as well as macroeconomic environment as the major challenges. As shown in Fig. 2, Rwanda has been ranked the best performer in the $1^{\text {st }}$ pillar of institutions, the $4^{\text {th }}$ pillar of health and primary, the $6^{\text {th }}$ pillar of goods market efficiency, the $7^{\text {th }}$ pillar of labor market efficiency, the $8^{\text {th }}$ pillar of financial market development. It is to be noted that in the $1^{\text {st }}$ pillar of institutions Rwanda has outperformed its neighboring and regional economies by a significant margin, Rwanda score 5.4 followed by Kenya with only 3.8 [4]. This is consistent with studies such as that conducted by Musonera et al [5] indicating a positive relationship between institutions fitness of Rwanda and FDI inflow. Rwanda is also among the best performer in the $12^{\text {th }}$ pillar of innovation, $11^{\text {th }}$ pillar of business sophistication, and $3^{\text {rd }}$ pillar of macroeconomic environment. In light of the above performance of Rwanda, it would be reasonable to argue Rwanda would take advantage of it to attract foreign investors including those attracted by resources in regional and neighboring countries.

This argument is based on criticisms of the diamond model for its explicit undermining of the role of country connectivity in the improvement of competitiveness [6-9].

According to critics, the home-based diamond can be enhanced by a stronger diamond of a more powerful trading partner; similarly, a country can tap into an external economy to fill the gap existing in its domestic diamond [10]. Subsequently, other models were suggested to explain the competitiveness of countries in a more comprehensive way. These include the nine factor model [11, 12], the double diamond $[\underline{6}, \underline{10}, \underline{13}]$, the double diamond model [14] and the multiple diamond [15-17].

This study argues that if considered alone, the Rwandan home-base diamond cannot have a significant explanatory 
power on FDI location choice given its existing disadvantage in certain factors within its domestic diamond such as its small market size, and limited natural resources. Its proximity and connectivity to other economies contributes greatly to addressing these challenges while exerting an enhancing effect. This is facilitated by regional integration agreements in place, geographic proximity, free movement of goods and people and any other cross-border transactions.

In this regard, basing on the diamond model, following the arguments put forth in the study conducted by Mahirwe et al [18] in relation to the improvement of the domestic diamond by tapping into external economies, this study extends the diamond model to include other factors from external economies which come to complement disadvantaged factors in the domestic diamond and exert an enhancing effect on their attractiveness toward foreign investors.

In fact, Rwanda shares borders with one of the potentially richest countries in the world [19], big in size, with huge amount of natural resources, rich flora and fauna and for that reason sometimes referred to as a "geological scandal" [20]. Its GDP was the same as that of Canada in 1960 at USD 3.35 billion, and same as that of South Korea in 1967. However, since 1996, the country has been plunged into wars and conflicts causing widespread insecurity and instability; this was coupled by weak institutions and political instability [19]. Natural resources remain one of the main determinants of FDI in developing countries [21]; however, potential risk due to political and social instability coupled with endemic warfare constitute a major concern for foreign investors thus a hindrance to FDI. In this study, we argue that the location choice of foreign investors in Rwanda may be influenced by its proximity to and influence in D.R. Congo which enjoys the sought after factors such as natural resources and market size but endures prevalent instability and inefficient institutions. Furthermore, the alleged influence of Rwanda in DRC [19] provides assurance to foreign investors of smooth business operations in relation to DRC.

Table 1: Trend of Ease of Doing Business (Rankings for selected economies)

\begin{tabular}{l|rrrrrrr} 
Year & 2006 & 2008 & 2010 & 2012 & 2014 & 2016 & 2018 \\
\hline Burundi & 160 & 174 & 176 & 169 & 140 & 152 & 164 \\
$\begin{array}{l}\text { Congo, } \\
\begin{array}{l}\text { Dem. Rep. } \\
\text { Kenya }\end{array}\end{array}$ & 175 & 178 & 182 & 178 & 183 & 184 & 182 \\
$\begin{array}{l}\text { Rwanda } \\
\text { Tanzania }\end{array}$ & 150 & 72 & 95 & 109 & 129 & 108 & 80 \\
\hline & 150 & 130 & 131 & 127 & 145 & 139 & 137 \\
\hline Uganda & 103 & 118 & 112 & 123 & 132 & 122 & 122 \\
\end{tabular}

Source: The World Bank Group (Doing Business Reports)
Figure 1: Corruption perception index

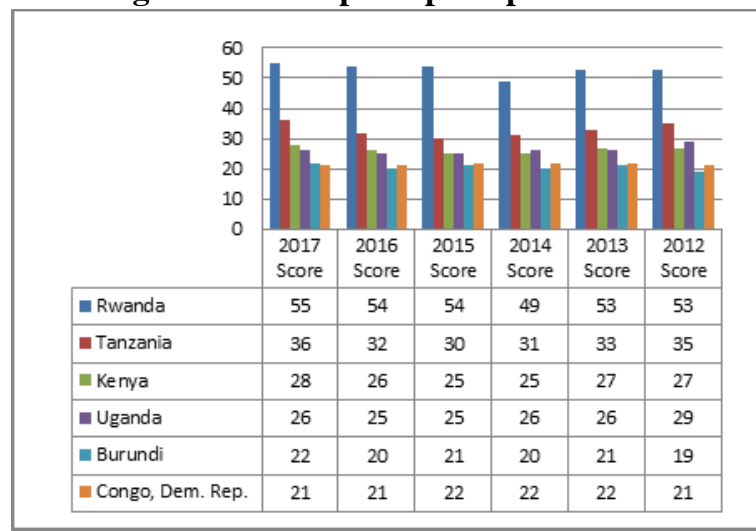

Source: Transparency International (Online database)

Figure 2: Global Competitiveness Index of Selected economies (2017-2018)

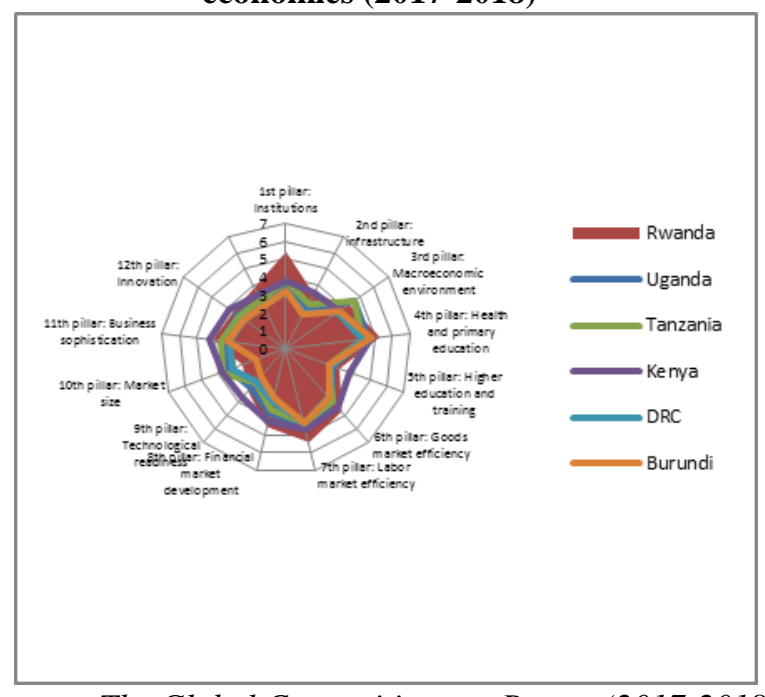

Source: The Global Competitiveness Report (2017-2018)

\section{THEORETICAL FRAMEWORK}

The literature has identified market size, natural resources as some of the determinants of FDI inflows in LDCs [2225]. On the other hand, political instability and malfunctioning institutions have been identified as deterrence to FDI [ $5, \underline{26-28}]$. Then the question is what happens to FDI targeting natural resources in countries with persistent instability and malfunctioning institutions? While we acknowledge that some FDI would still locate in some countries despite the prevailing instability and weak institutions Kim [29], but consistence with the mainstream literature, it is logical to assume that the absence of effective institutions would alter the location choice of FDI; in fact, political stability play a decisive role in FDI location choice to developing countries $[\underline{30}, \underline{31}]$.

In fact, FDI may be driven to a country due to its proximity to location specific advantages of neighboring countries rather than its own. To this point, this scenario has been overlooked by previous studies. In fact, FDI may be attracted to a country not because of what it can offer in terms of its own specific advantage, but because of the ease 
and convenience it offers to access input materials from another country in its neighborhood where those resources are relatively abundant. However, this scenario occurs when some of FDI determinants which are vital for smooth business operations are not available in the country with abundance of natural resources but available in another country which is less endowed in natural resources. For instance, a country with good institutions but challenged in natural resources may attract FDI in its economy which are targeting natural resources from neighboring countries with poor institutions; thus, in this case proximity, coupled with good institutions of that country enhance the attractiveness of that country and serve as determinants of FDI.

In light of the above, this study argues that the attractiveness of the host country toward FDI can be enhanced by neighboring countries' specific advantages.

In light with the above, this study has developed a simple model which facilitates the computation of proximity as a variable. Basing on the theory of Liability of Foreignness (LOF), as trade between countries increases, they become familiar to each other, thus decreasing the level of LOF. That is, as countries interact trough import and export transactions, their closeness in terms of different aspects of life increases, this include but not limited to culture, language, legal system, business practice; over time, any impediment of business transactions between them fade away [32]. In some cases, the interaction of countries through trade acts as a motivation for countries to achieve greater integration which lead to a virtual elimination of territorial borders. In other words, the increase of interaction through trade reduces LOF. Consistent with the dyadic perspective of LOF $[33,34]$, we expect the proximity to be conditioned by trade between Rwanda and other regional countries in relation to trade of Rwanda with the rest of the world. In this study, we consider regional countries to include Uganda, D.R. Congo, Burundi, Tanzania, and Kenya. In this regard, Proximity can be expressed as follows:

$$
P_{i, j}=\frac{\sum_{j=1}^{n} T_{i, j, t}}{T_{i, w, t}-\sum_{j=1}^{n} T_{i, j, t}}
$$

This can also be rewritten as:

$$
P_{i, j}=\frac{\sum_{j=1}^{n} T_{i, j, t}}{T_{i,(w-j), t}}
$$

Where: $P_{i, j}$ denotes Proximity between country $i$ and group of countries $j$, and $T_{i, j}$ denotes Trade between country $i$ and group of countries $j$. The denominator $T_{i,(w-j)}$ represents trade between country $i$ and the rest of the world $(w-j) . \quad t$ represents the time during which trade was conducted.

Our trade data will be sourced from The Observatory of Economic Complexity (OEC) online database.

\section{METHODOLOGY AND MODEL SPECIFICATION}

\section{A. Model specification}

This study uses time series; Johansen Cointegration and VECM are used to investigate the influence of proximity on FDI inflow.
Unit root test has to be run to ensure that no variable is integrated of order two I (2). After determining the optimal lag structure, Johansen cointegration test will be ran to find out if there is a long-run cointegration relationship in our model.

VECM model will be specified in the following form:

$$
\begin{aligned}
V E C M: \Delta y_{t}=\beta_{0} & +\sum_{i=1}^{n} \beta_{i} \Delta y_{t-i}+\sum_{i=1}^{n} \beta_{i} \Delta x_{t-i}+E C T_{t-1} \\
& +\mu_{t}
\end{aligned}
$$

Where: $y$ represents the target variable, $x$ represents the used regressors, $\beta_{0}$ represents the constant, $\beta_{i}$ represent the coefficients.

The cointegrating equation is specified in the following form:

$$
E C T_{t-1}=y_{t-1}-\beta_{0}-\beta_{1} x_{t-1}
$$

\section{B. Data Source and description}

The data sample used by this study was sources from online database of World Development Indicators, from year 1970 to 2017 .

Target variable:

FDI inflow: Foreign direct investment, net inflows (\% of GDP)

\section{Regressors:}

Proximity: This variable was computed as per the model specified above.

Education (proxied by school enrollment): School enrollment, secondary ( $\%$ gross).

Trade openness: Trade ( $\%$ of GDP).

ODA (logarithm term): Net official development assistance and official aid received (constant 2015 US\$).

NAT: Total natural resources rents (\% of GDP).

Market size (proxied by GDP (logarithm term): GDP per capita (constant 2010 US\$).

Infrastructure: proxied by Fixed telephone subscriptions (per 100 people)

\section{Dummy variables:}

The analysis of our data indicate a structural breakpoint, a dummy variable (dum_break) was constructed to account for the breakpoint. To find the exact structural breakpoint, Chow test was ran. The year 2006 was found to be the starting point of the structural break. This structural break indicates a period of lasting peace and stability in the country. The diagnostic test for the constructed dummy variable included stability test (Recursive estimatesCUSUM of Squares Test) which indicated that the model is stable (within 5\% significance).

\section{EMPIRICAL TESTING AND DISCUSSION OF FINDINGS\& RESULTS}

Out unit root test reveal that some of our variables are stationary at level I (0) and while others are stationary at first difference I (1), this sanctions the use of VECM in this particular case. 
According to the Akaike information criterion (See Table $1)$, the optimal lag length is two (2).

\section{Johansen Cointegration test}

Johansen cointegration test indicates the presence of longrun cointegration; the trace test indicates the presence of cointegrating equations at $5 \%$ level.

The above results indicate the following:

In the long-run, proximity, trade openness, and GDP per capita have a positive impact on FDI inflow, on average, ceteris paribus. The coefficients are statistically significant at the $1 \%$ level.

Education and foreign aid have a negative impact on FDI inflow on average, ceteris paribus. The coefficients are statistically significant at the $1 \%$ level.

In light of the above results, the null hypothesis of no cointegration is rejected against the alternative of a cointegration relationship in the model. Therefore, the test of VECM is sanctioned.

Table 2: Johansen normalization results and interpretation

\begin{tabular}{|l|l|l|l|l|l|l|l|l|}
\hline & PROXTY & SCH1 & OPEN & LODA1 & NAT & LGDP1 & LFIXTEL1 & BREAK \\
\hline $\begin{array}{l}\text { Normalized } \\
\text { cointegrating } \\
\text { coefficients }\end{array}$ & -2.87912 & 0.03193 & -0.10138 & 0.745171 & 0.035741 & -2.57793 & 0.029433 & -0.01182 \\
\hline $\begin{array}{l}\text { standard } \\
\text { error }\end{array}$ & -0.59794 & -0.01293 & -0.00712 & -0.1886 & -0.02172 & -0.23343 & -0.05403 & -0.15133 \\
\hline \begin{tabular}{l} 
T statistics \\
\hline
\end{tabular} & 4.815058 & -2.46945 & 14.23933 & -3.95107 & -1.64553 & 11.04368 & -0.54475 & 0.078114 \\
\hline
\end{tabular}

\section{VECM Findings}

The VECM results reveal the following;

The adjustment coefficient: The previous period's deviation from long-run equilibrium is corrected at a speed of $97 \%$.

Previously accumulated FDI inflow: A percentage change in previously accumulated FDI inflow is associated with a 0.27 decrease in new FDI inflow, on average, ceteris paribus, in the short-run.

Proximity: A percentage change in proximity is associated with a 1.51 decrease in FDI inflow, on average, ceteris paribus, in the short-run.

Foreign aid (ODA): A percentage change in proximity is associated with a 1.19 increase in FDI inflow, on average, ceteris paribus, in the short-run.

Infrastructure (proxied by fixed telephone): A percentage change in infrastructure is associated with a 1.80 increase in FDI inflow, on average, ceteris paribus, in the short-run.

\section{E. Wald Test}

The Wald test shows indicates that the null hypothesis is rejected, the null hypothesis being that proximity does not granger cause FDI inflow. We can therefore assert that proximity granger cause FDI inflow.

\begin{tabular}{|l|l|l|l|}
\hline \multicolumn{2}{|l|}{ Wald Test: } & & \\
\hline Equation: Untitled & & \\
\hline Test Statistic & Value & df & Probability \\
\hline t-statistic & -2.165921 & 30 & 0.0384 \\
\hline F-statistic & 4.691216 & $(1,30)$ & 0.0384 \\
\hline Chi-square & 4.691216 & 1 & 0.0303 \\
\hline
\end{tabular}

\section{F. Diagnostics test}

The normality test; according to normality test results, we fail to reject the null hypothesis; this suggests that there is no indication of serial correlation.

Autocorrelation LM test: According to the autocorrelation LM test, we fail to reject the null hypothesis; therefore, there is no serial correlation.

The stability test (Recursive estimates-CUSUM Test) indicates that the model is stable (within 5\% significance).

\section{CONCLUSION}

The purpose of this study was to investigate if a country with limited natural resources can benefit from its geographic location due to the presence of countries in its neighborhood which are rich in natural resources. This study asserted that to benefit from other countries factors endowments, a country has to focus on enhancing other factors which are poorly achieved in neighboring countries. This study found that by focusing on improving investment and regulatory environment, Rwanda has tremendously benefited from its proximity with countries rich in natural resources but with low performance in terms of regulations and investment climate. The Johansen test reveals that in the long run, proximity exerts a positive influence on FDI inflow. However, as revealed by VECM test, in the short run the country may not benefit as it requires time to develop its investment and regulatory institutions.

Other important findings revealed that in the long-run, trade openness, and GDP per capita have a positive impact on FDI inflow, while education and foreign aid have a negative impact on FDI inflow in the long run.

\section{REFERENCES}

1. NISR, Statistical Yearbook 2017, 2017, National Institute of Statistics of Rwanda.

2. Bank, W., Doing Business 2017: Equal Opportunity for All, 2017: Washington DC.

3. World Bank Group, Doing Business 2018, 2018: Washington DC 20433.

4. World Economic Forum, The Global Competitiveness Report 2017 2018, 2018: Geneva.

5. Musonera, E., E. Karuranga, and B.I. Nyamulinda, Institution fitness, investment and economic growth in Rwanda. The Journal of International Business Research and Practice (JIBRP) Volume 8, 2014, 2014. 8: p. 117.

6. Dunning, J.H., The role of foreign direct investment in upgrading China's competitiveness. Journal of

International Business and Economy, 2003. 4(1): p. 1-13.

Published By: 
7. Dunning, J.H., Internationalizing Porter's diamond. MIR Management International Review, 1993: p. 7-15.

8. Rugman, A.M., Porter takes the wrong turn. Business Quarterly, 1992. 56(3): p. 59-64.

9. Chang Moon, H., A.M. Rugman, and A. Verbeke, The generalized double diamond approach to international competitiveness, in Beyond the diamond. 1995, Emerald Group Publishing Limited. p. 97-114.

10. Rugman, A.M. and J.R. D'cruz, The" double diamond" model of international competitiveness: The Canadian experience. MIR Management International Review, 1993: p. 17-39.

11. Cho, D.-S., A dynamic approach to international competitiveness: The case of Korea. Asia pacific business review, 1994. 1(1): p. 17-36.

12. Cho, D.-S. and H.-C. Moon, From Adam Smith to Michael Porter: evolution of competitiveness theory. 2000: World Scientific.

13. Moon, H.C., A.M. Rugman, and A. Verbeke, A generalized double diamond approach to the global competitiveness of Korea and Singapore. International business review, 1998. 7(2): p. 135-150.

14. Cho, D.-S., H.-C. Moon, and M.-Y. Kim, Characterizing international competitiveness in international business research: A MASI approach to national competitiveness. Research in International Business and Finance, 2008. 22(2): p. 175-192.

15. Cartwright, W.R., Multiple linked" diamonds" and the international competitiveness of export-dependent industries: The New Zealand experience. MIR: Management International Review, 1993: p. 55-70.

16. O'Malley, E. and C. Van Egeraat, Industry clusters and Irish indigenous manufacturing: Limits of the Porter view. Economic and social review, 2000. 31(1): p. 55-79.

17. Rugman, A.M. and A. Verbeke, Foreign subsidiaries and multinational strategic management: an extension and correction of Porter's single diamond framework. MIR: Management International Review, 1993: p. 71-84.

18. Mahirwe, A.M. and L. Wei, Investigation of Competitive Advantage of the Dairy Industry Cluster: The Case of Rwanda. American Journal of Industrial and Business Management, 2018. 8(05): p. 1358.

19. Kisangani, E.F., Historical dictionary of the Democratic Republic of the Congo. 4th ed. 2016: Rowman \& Littlefield.

20. Kisangani, E.F. and F.S. Bobb, Historical dictionary of the Democratic Republic of the Congo. 3rd ed. 2010: The Scarecrow Press, Inc.

21. UNCTAD, World Investment Report 2017, in United Nations Conference on Trade and Development (UNCTAD) World Investment Report (WIR)2017, United Nations.

22. Amponsah, W.A. and P. Garcia-Fuentes, Do Market Size and Remittances Explain Foreign Direct Investment Flows to Sub-Sahara Africa?, in Investment and Competitiveness in Africa, D. Seck, Editor. 2017, Springer International Publishing: Cham. p. 87-107.

23. Drogendijk, R. and K. Blomkvist, Drivers and motives for Chinese outward foreign direct investments in Africa. Journal of African Business, 2013. 14(2): p. 75-84.

24. Balinda, S.N., Factors Attracting Foreign Direct Investments (FDIs) in Rwanda: The Case of Selected Companies. Soudi Journal of Business and Management Studies, 2016. 7(8.6): p. 94.2.

25. Bokpin, G.A., L. Mensah, and M.E. Asamoah, Foreign direct investment and natural resources in Africa. Journal of Economic Studies, 2015. 42(4): p. 608-621.

26. Suliman, A.H. and A.V. Mollick, Human capital development, war and foreign direct investment in sub-Saharan Africa. Oxford Development Studies, 2009. 37(1): p. 47-61.

27. Cleeve, E., Political and institutional impediments to foreign direct investment inflows to sub-Saharan Africa. Thunderbird International Business Review, 2012. 54(4): p. 469-477.

28. Asiedu, E., Foreign direct investment in Africa: The role of natural resources, market size, government policy, institutions and political instability. The World Economy, 2006. 29(1): p. 63-77.

29. Kim, H., Political stability and foreign direct investment. International Journal of Economics and Finance, 2010. 2(3): p. 59.

30. Blonigen, B.A., A Review of the Empirical Literature on FDI Determinants. Atlantic Economic Journal, 2005. 33(4): p. 383-403.

31. Denisia, V., Foreign direct investment theories: An overview of the main FDI theories. 2010.

32. Zaheer, S. and E. Mosakowski, The dynamics of the liability of foreignness: A global study of survival in financial services. Strategic management journal, 1997. 18(6): p. 439-463.

33. Sethi, D. and S. Guisinger, Liability of foreignness to competitive advantage: How multinational enterprises cope with the international business environment. Journal of International Management, 2002. 8(3): p. 223-240.

34. Luo, Y. and J.M. Mezias, Liabilities of foreignness: Concepts constructs, and consequences. Journal of International Management, 2002. 8(3): p. 217-221. 